\title{
PENENTUAN STATUS MUTU AIR TANAH DI KECAMATAN MADURAN KABUPATEN LAMONGAN
}

\section{Determination of Water Quality Status in Maduran District Lamongan}

\author{
Maulidiyah Nor Kasanah ${ }^{1}{ }^{\star}$, Shinfi Wazna Auvaria, Widya Nilandita
}

${ }_{1}^{1}$ Program Studi Teknik Lingkungan Universitas Islam Negeri Sunan Ampel, Jl. Ahmad Yani No 117, Surabaya 60237, Indonesia

\begin{abstract}
Water is a component of supporting basic human needs for daily activities. Maduran District is a sub-district whose inhabitants use groundwater as an alternative water source. The factors of contamination of groundwater in Maduran District are household activities, home industry and the agricultural sector. The purpose of this study was to determine the quality and status of groundwater quality in Maduran District. Groundwater quality status is based on Permenkes No. 32 of 2017 and Kepmenlh No. 115 of 2003. The sampling station is determined based on SNI 6989.58: 2008. Sampling was done once with the split method at 8 representative stations. The groundwater quality status test includes physical and chemical parameters, namely temperature, smell, taste, TDS, turbidity, $\mathrm{pH}, \mathrm{CaCO}, \mathrm{Mn}, \mathrm{Fe}$, Nitrate, and Nitrite. The results of the analysis of groundwater quality contained parameters that exceeded the standard, namely, Station A with TDS levels of $2490 \mathrm{mg} L^{-1}$ and hardness of $1,130 \mathrm{mg} \mathrm{L}^{-1}$. Station D has a TDS level of 1,284 $\mathrm{mg} \mathrm{L}^{-1}$ and a hardness of $500 \mathrm{mg} \mathrm{L}^{-1}$. Meanwhile, Station H has a TDS level of $1,389 \mathrm{mg} \mathrm{L}^{-1}$. The status of water quality using the IP method shows Station A, Station D, and Station H are categorized as light polluted. Meanwhile, Station B, Station C, Station E, Station F, and Station G are categorized as Fulfilling Quality Standards.
\end{abstract}

Keywords: Water Quality, Water Quality Status, Pollution Index Method

\section{ABSTRAK}

Air merupakan komponen penunjang kebutuhan pokok manusia untuk kegiatan sehari-hari. Kecamatan Maduran menjadi kecamatan yang penduduknya menggunakan air tanah sebagai sumber air alternatif. Faktor adanya kontaminasi terhadap air tanah di Kecamatan Maduran adalah kegiatan rumah tangga, home industry, dan sektor pertanian. Tujuan dari penelitian ini adalah mengetahui kualitas dan status mutu air tanah di Kecamatan Maduran. Status mutu air tanah didasarkan pada Permenkes No. 32 Tahun 2017 dan Kepmenlh No. 115 Tahun 2003. Stasiun pengambilan sampel ditentukan berdasarkan SNI 6989.58:2008. Pengambilan sampel dilakukan 1 kali dengan metode split di 8 stasiun yang mewakili. Pengujian status mutu air tanah meliputi parameter fisik dan kimia, yaitu suhu, bau, rasa, TDS, kekeruhan, $\mathrm{pH}, \mathrm{CaCO}_{3}, \mathrm{Mn}, \mathrm{Fe}$, Nitrat, dan Nitrit. Hasil analisis kualitas air tanah terdapat parameter yang melebihi baku yaitu, Stasiun A dengan kadar TDS senilai 2,490 mg L-1 dan Kesadahan senilai $1,130 \mathrm{mg} \mathrm{L}^{-1}$. Stasiun D kadar TDS senilai 1,284 mg L ${ }^{-1}$ dan kesadahan $500 \mathrm{mg} \mathrm{L}^{-1}$. Sedangkan, Stasiun H kadar TDS senilai $1,389 \mathrm{mg} \mathrm{L}^{-1}$. Status mutu air menggunakan metode IP menunjukkan Stasiun A, Stasiun D, dan Stasiun H dikategorikan sebagai Cemar Ringan. Sedangkan, Stasiun B, Stasiun C, Stasiun E, Stasiun F, dan Stasiun G dikategorikan sebagai Memenuhi Baku Mutu.

Kata Kunci: Air Tanah, Status Mutu Air, Metode Indeks Pencemaran

\section{PENDAHULUAN}

Air merupakan komponen kebutuhan pokok bagi manusia untuk kegiatan sehari-hari. Sekitar 30\% setiap hari konsumsi air di dunia diperoleh dari air tanah (Azis et al., 2015).

Air tanah yang berada dibawah permukaan tanah mengalami pergerakan dalam ruang-ruang antar butir tanah yang dapat membentuk ikatan dan retakan batuan (Nurraini, 2011). Air tanah di seluruh dunia digunakan untuk kebutuhan domestik dan suplai industri, serta irigasi (Dohare et al., 2014).

Dokumen Informasi Kinerja Pengelolaan Lingkungan Hidup (IKPLHD) Kabupaten Lamongan Tahun 2016 menyatakan bahwa air tanah merupakan alternatif sumber air untuk memenuhi kebutuhan air bersih di Kabupaten Lamongan, namun dari segi kualitas dan kuantitas masih memiliki keterbatasan.
Kecamatan Maduran menjadi kecamatan yang penduduknya menggunakan air tanah sebagai sumber air alternatif. Faktor kontaminasi terhadap air tanah di Kecamatan Maduran dapat disebabkan oleh aktivitas rumah tangga, home industry, dan sektor pertanian.

Kontaminasi pada air tanah akan berdampak pada kualitas air minum yang buruk, kerusakan pada sistem air permukaan, serta adanya potensi penyakit menular bagi manusia (Pawari \& Gawande, 2015).

Analisis kualitas air tanah berdasakan standar baku mutu Peraturan Menteri Kesehatan Republik Indonesia Nomor 32 Tahun 2017. Penentuan status mutu air tanah menggunakan metode indeks pencemaran pada Peraturan Menteri Lingkungan Hidup No. 115 Tahun 2003. Kelebihan dari metode indeks pencemaran

Tujuan dari penelitian ini adalah 1) mengetahui kualitas air tanah berdasarkan parameter fisik dan kimia, 2) mengetahui status mutu air tanah menggunakan metode indeks pencemaran. 


\section{BAHAN DAN METODE}

\section{Lokasi dan Waktu Penelitian}

Penelitian berlokasi di Kecamatan Maduran, Kabupaten Lamongan yang terbagi menjadi 8 stasiun yang mewakili, yaitu Stasiun A (Desa Brumbun), Stasiun B (Desa Klagen Srampat), Stasiun C (Desa Pangean), Stasiun D (Desa Maduran), Stasiun E (Desa Parengan), Stasiun F (Desa Gedangan), Stasiun G (Desa Kanugrahan), dan Stasiun H (Desa Ngayung). Waktu pelaksanaan penelitian dan analisis hasil dilaksanakan mulai bulan Januari 2020 hingga Desember 2020.

\section{Alat dan Bahan}

Alat yang digunakan adalah cool box, meteran, jerigen, pH meter, Termometer, Global Positioning System (GPS), Software ArcGIS 10.7, Google Earth, dan Microsoft Office. Sedangkan bahan yang digunakan adalah sampel air tanah dan aquades.

\section{Metode Penelitian}

Metode penelitian adalah deskriptif-kualitatif dengan menganalisis kualitas air dan status mutu air yang meliputi parameter fisik yang terdiri dari parameter bau, rasa, zat padat terlarut (TDS), dan kekeruhan serta parameetr kimia yang terdiri dari parameter $\mathrm{pH}$, Besi $(\mathrm{Fe})$, Mangan (Mn), dan Kesadahan $\left(\mathrm{CaCO}_{3}\right)$.

\section{Pengambilan Sampel}

Pengambilan sampel dengan metode Purposive Sampling. Stasiun pengamatan dipilih berdasarkan pada SNI 6989.58:2008 tentang Metode Pengambilan Contoh Air Tanah. Titik koordinat stasiun pengamatan menggunakan Google Earth. Terdapat 8 stasiun yang mewakili Kecamatan Maduran Kabupaten Lamongan, seperti pada Gambar 1.

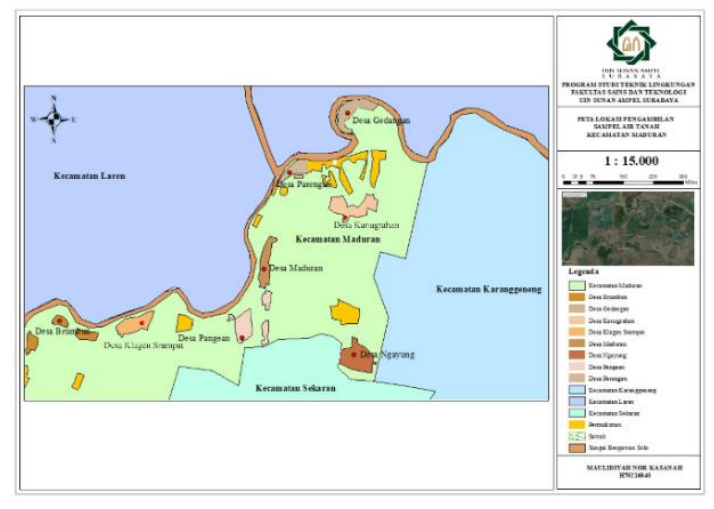

Gambar 1. Peta Lokasi Pengambilan Sampel Air Tanah

Tahap Analisis Data

Konsentrasi parameter fisik dan kimia kemudian dihitung dan dianalisis menggunakan Metode Indeks Pencemaran (IP) berdasarkan pada Kepmenlh No.115 Tahun 2003. Hasil perhitungan IP untuk mengetahui status mutu air disajikan pada tabel 1. Rumus Indeks Pencemaran
(IP) untuk mengetahui status mutu air, adalah sebagai berikut:

$$
P I_{j}=\sqrt{\left(C_{i} / L_{i j}\right)_{M}^{2}+\left(C_{i} / L_{i j}\right)_{R}^{2}}
$$

\section{Keterangan:}

IPj : Indeks Pencemaran bagi peruntukan j

$\mathrm{Ci}$ : Konsentrasi hasil uji parameter

Lij : Konsentrasi parameter sesuai baku mutu peruntukan air $\mathrm{j}$

(Ci/ Lij)M : Nilai Ci/Lij maksimum

$(\mathrm{Ci} / \mathrm{Lij}) \mathrm{R}$ : Nilai Ci/Lij rata-rata

Tabel 1. Skor Indeks Pencemaran

\begin{tabular}{ccl}
\hline No. & Skor Indeks Pencermaran & \multicolumn{1}{c}{ Deskripsi } \\
\hline 1. & $0-1,0$ & Kondisi Baik \\
2. & $1,1-5,0$ & Cemar Ringan \\
3. & $5,1-10$ & Cemar Sedang \\
4. & $>10$ & Cemar Berat \\
\hline
\end{tabular}

HASIL DAN PEMBAHASAN

\section{Analisis Konstruksi Sumur Gali}

Konstruksi sumur gali stasiun pengambilan sampel terbuat dari beton, dengan kedalaman yang bervariasi antara 1 meter hingga 20 meter dari permukaan tanah dengan bergantung pada ketinggian muka air tanah dan kondisi morfologi lingkungan sekitarnya.

\section{Analisis Kualitas Fisik Air Tanah}

Parameter fisik yang dianalisis yaitu suhu, kekeruhan, bau, rasa, dan total padatan terlarut. Nilai konsentrasi tiap parameter di bandingkan dengan Permenkes No. 32 Tahun 2017 untuk kebutuhan Higiene Sanitasi, yang disajikan pada gambar dan tabel berikut ini:

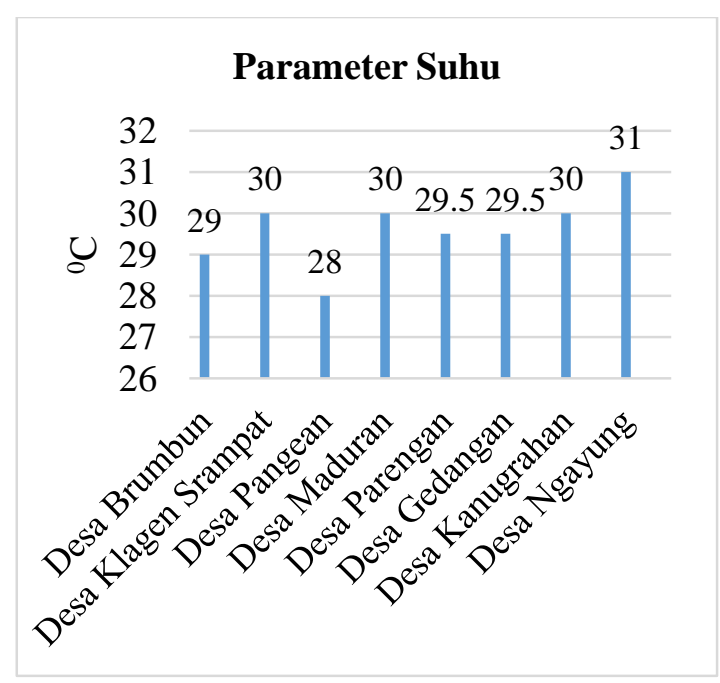

Gambar 2. Nilai Suhu Air Tanah di Kecamatan Maduran

Pengujian parameter suhu pada Gambar 2, menunjukkan hasil bervariasi yaitu $28{ }^{\circ} \mathrm{C}$ hingga $31{ }^{\circ} \mathrm{C}$. Stasiun $\mathrm{C}$ suhu $28{ }^{\circ} \mathrm{C}$ termasuk sesuai baku mutu. Suhu diatas $28{ }^{\circ} \mathrm{C}$ termasuk di atas baku mutu yaitu Stasiun A, Stasiun B, Stasiun D, Stasiun E, Stasiun F, Stasiun G, dan Stasiun $\mathrm{H}$ dengan suhu rata-rata berkisar $29{ }^{\circ} \mathrm{C}$ hingga 31 
${ }^{\circ} \mathrm{C}$. Nilai suhu yang tinggi di stasiun $\mathrm{H}$ dapat dikaitkan dengan waktu pengambilan sampel dan pengukuran lapangan yang dilakukan siang hari, sehingga suhu air tanah sama dengan suhu udara.

Umumnya suhu air tanah bergantung dengan ketinggian topografi daerahnya (Lee \& Hahn, 2006). Suhu tinggi berpengaruh pada mikroorganisme sehingga tidak dapat menguraikan bahan organi. Selain itu, dapat mempengaruhi kadar DO. Jika kadar DO menurun akan mempengaruhi kehidupan biota dalam air, apabila perairan tidak memiliki kadar oksigen akan membentuk kondisi anaerobik dan menyebabkan bau busuk (Ningrum, 2018).

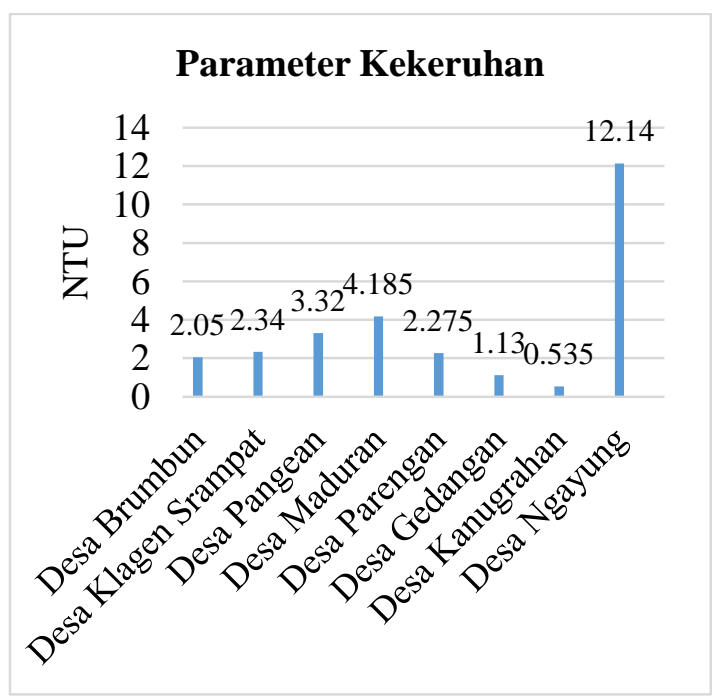

Gambar 3. Nilai Kekeruhan Air Tanah di Kecamatan Maduran

Pengujian parameter kekeruhan pada Gambar 3, nilai kekeruhan tertinggi di Stasiun H senilai 12.14 NTU. Sedangkan, stasiun lainnya memiliki nilai rata-rata senilai >5 NTU. Nilai kekeruhan di seluruh stasiun sesuai baku mutu yang ditetapkan yaitu 25 NTU. Nilai kekeruhan stasiun $\mathrm{H}$ yang lebih tinggi dapat disebabkan kondisi disekitar sumur gali adalah tanah berpasir. Nilai kekeruhan di stasiun ini dapat dikaitkan dengan nilai total padatan terlarut senilai $1,389 \mathrm{mg} \mathrm{L}^{-1}$.
Kekeruhan dapat disebabkan oleh zat organik dan non-organik yang tersuspensi dan terlarut, seperti lumpu dan pasir halus (Azis et al., 2015).

Nilai kekeruhan yang tinggi pada air akan mempengaruhi warna air. Kondisi ekologis disekitar lokasi sumber air akan mempengaruhi nilai kekeruhan. Semakin tinggi nilai kekeruhan pada air maka semakin tinggi pula resiko air terkontaminasi oleh sumber pencemar (Citaningtyas, 2019).

Pengujian parameter bau pada Tabel 2, menunjukkan 2 stasiun yang berbau dan 6 stasiun tidak berbau. Hasil analisis mengindikasikan bahwa kondisi air tanah di Stasiun D dan Stasiun E adalah berbau. Bau pada sampel air tanah dapat dihubungkan oleh adanya aktivitas bakteri yang masuk kedalam sumur gali. Sumur gali di Stasiun D berdekatan dengan tangki septik. Sedangkan, sumur gali di Stasiun E berada disekitar home industry sarung tenun serta berdekatan dengan tangki septik.

Faktor penyebab adanya indikasi bau pada air adalah adanya mikroorganisme, limbah rumah tangga, industri, maupun tempat pengolahan sampah (Hapsari, 2015).

Pengujian parameter rasa pada Tabel 3, 4 stasiun dengan kondisi air berasa dan 4 lokasi lainnya tidak berasa. Hasil analisis mengindikasi bahwa kualitas air tanah di Stasiun A, B, D dan G memiliki air yang berasa. Sedangkan, 4 stasiun dengan indikasi tidak berasa adalah Stasiun C, E, $\mathrm{F}$, dan $\mathrm{H}$.

Pengujian parameter TDS pada Gambar 4, terdapat 3 lokasi yang melebihi baku mutu dan 5 lokasi lainnya memiliki nilai dibawah baku mutu. Menurut, Permenlh No.32 Tahun 2017 baku mutu TDS senilai 1,000 mg L-1. Stasiun dengan nilai TDS tertinggi adalah Stasiun A, D, dan H. Kandungan TDS Stasiun A sebesar 2,490 mg L $\mathrm{m}^{-1}$, yang disebabkan oleh lokasi sumur gali berjarak <1 meter dari tangki septik dan selokan. Kandungan TDS Stasiun D sebesar 1,283.5 $\mathrm{mg} \mathrm{L}^{-1}$ disebabkan oleh jarak sumur gali <2 meter dari tangki septik dan saluran pembuangan. Sedangkan, nilai TDS Stasiun $\mathrm{H}$ sebesar 1,389 $\mathrm{mg} \mathrm{L}^{-1}$ disebabkan oleh sumur gali berdekatan dengan saluran buangan limbah dan kondisi tanah berpasir.

Tabel 2. Analisa Parameter Bau Air Tanah di Kecamatan Maduran

\begin{tabular}{|c|c|c|c|c|c|}
\hline Lokasi & Stasiun & Hasil & Baku Mutu & Satuan & Keterangan \\
\hline Desa Brumbun & $\mathrm{A}$ & Tidak Berbau & \multirow{8}{*}{ Tidak Berbau } & \multirow[t]{8}{*}{ (1) } & Sesuai \\
\hline Desa Klagen Srampat & $\mathrm{B}$ & Tidak Berbau & & & Sesuai \\
\hline Desa Pangean & $\mathrm{C}$ & Tidak Berbau & & & Sesuai \\
\hline Desa Maduran & $\mathrm{D}$ & Berbau & & & Tidak Sesuai \\
\hline Desa Parengan & $\mathrm{E}$ & Berbau & & & Tidak Sesuai \\
\hline Desa Gedangan & $\mathrm{F}$ & Tidak Berbau & & & Sesuai \\
\hline Desa Kanugrahan & G & Tidak Berbau & & & Sesuai \\
\hline Desa Ngayung & $\mathrm{H}$ & Tidak Berbau & & & Sesuai \\
\hline
\end{tabular}

Tabel 3. Analisa Parameter Rasa Air Tanah di Kecamatan Maduran

\begin{tabular}{|c|c|c|c|c|c|}
\hline Lokasi & Stasiun & Hasil & Baku Mutu & Satuan & Kesesuaian dengan Baku Mutu \\
\hline Desa Brumbun & A & Berasa & \multirow{8}{*}{ Tidak Berasa } & \multirow{8}{*}{ 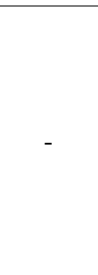 } & Tidak Sesuai \\
\hline Desa Klagen Srampat & B & Berasa & & & Tidak Sesuai \\
\hline Desa Pangean & $\mathrm{C}$ & Tidak Berasa & & & Sesuai \\
\hline Desa Maduran & $\mathrm{D}$ & Berasa & & & Tidak Sesuai \\
\hline Desa Parengan & $\mathrm{E}$ & Tidak Berasa & & & Sesuai \\
\hline Desa Gedangan & $\mathrm{F}$ & Tidak Berasa & & & Sesuai \\
\hline Desa Kanugrahan & G & Berasa & & & Tidak Sesuai \\
\hline Desa Ngayung & $\mathrm{H}$ & Tidak Berasa & & & Sesuai \\
\hline
\end{tabular}




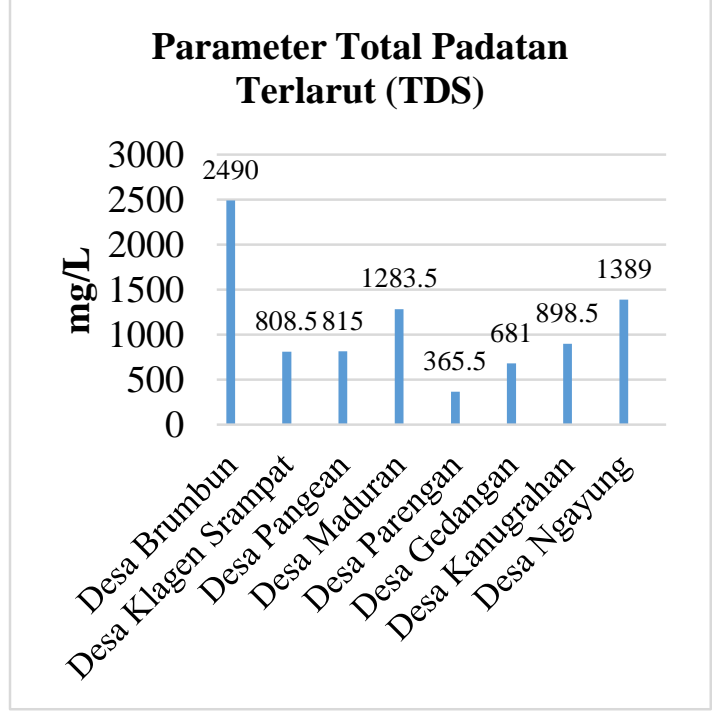

Gambar 4. Nilai TDS Air Tanah di Kecamatan Maduran

Nilai TDS berbanding lurus dengan nilai kekeruhan pada air, yaitu jika TDS tinggi maka semakin tinggi juga nilai kekeruhan (Suryana H., 2013). Air dengan nilai TDS $<1,500 \mathrm{mg} \mathrm{L}^{-1}$ memiliki rasa yang tidak enak dan tidak baik untuk dikonsumsi sebagai air minum. TDS berkaitan dengan nilai kesadahan, tingkat kekeruhan, serta salinitas (Fajarini, 2014). Kontaminasi padatan terlarut berasal dari zat organik, garam, dan gas terlarut. Jika air mengandung padatan terlarut diminum akan mempengaruhi fungsi fisiologis ginjal (Afrianita et al., 2017).

Pengujian parameter $\mathrm{pH}$ pada Gambar 5, menunjukkan kadar $\mathrm{pH}$ air tanah adalah antara 7.4 hingga 8.65 masuk dalam kondisi basa. Baku mutu yang ditetapkan adalah 6.5 hingga 8.5. Kadar $\mathrm{pH}$ pada Stasiun G tertinggi yaitu 8.65, sehingga air tidak layak dikatakan sebagai air bersih. Tingginya nilai $\mathrm{pH}$ diduga karena stasiun pengambilan sampel berdekatan dengan saluran pembuangan limbah serta kandang ternak. Sedangkan, Nilai $\mathrm{pH}$ di Stasiun lainnya sesuai dengan baku mutu.

Tinggi dan rendahnya nilai $\mathrm{pH}$ di dalam air tidak berpengaruh pada kesehatan tetapi, jika air dengan kadar $\mathrm{pH}$ lebih kecil dari 6.5 dapat menyabkan korosi pada metal (pipa air). Sebaliknya, air tanah dengan nilai $\mathrm{pH}$ yang lebih besar dari 8.5 dapat menyebabkan endapan atau kerak pada pipa air yang kemudian dapat menyebabkan sifat racun (Fajarini, 2014).

\section{Analisis Kualitas Kimia Air Tanah}

Pengujian parameter Fe pada Gambar 6, menunjukkan bahwa Stasiun D memiliki kandungan besi tertinggi sebesar $0.11 \mathrm{mg} \mathrm{L}^{-1}$. Sedangkan, Stasiun A dengan kandungan besi terendah yaitu $0.01 \mathrm{mg} \mathrm{L}^{-1}$. Tetapi, nilai Fe pada air tanah di Kecamatan Maduran masih dibawah baku mutu, yaitu $1 \mathrm{mg} \mathrm{L}^{-1}$.

Pengujian Parameter Kesadahan $\left(\mathrm{CaCO}_{3}\right)$ pada Gambar 7, menunjukkan nilai Kesadahan di Stasiun A diatas baku mutu sebesar 1,130 $\mathrm{mg} \mathrm{L}^{-1}$. Stasiun D dan Stasiun F memiliki nilai Kesadahan yang sesuai dengan baku mutu yaitu $500 \mathrm{mg} \mathrm{L}^{-1}$. Stasiun lainnya dibawah baku mutu. Stasiun A dengan kandungan kesadahan tinggi ditandai dengan sulitnya sabun untuk berbusa. Kandungan kesadahan di atas $100 \mathrm{mg} \mathrm{L}^{-1}$ dapat mengakibatkan karat pada peralatan rumah tangga, sedangkan nilai kesadahan di atas $300 \mathrm{mg} \mathrm{L}^{-1}$ dapat menyebabkan gangguan pada ginjal (Astuti et al., 2016).

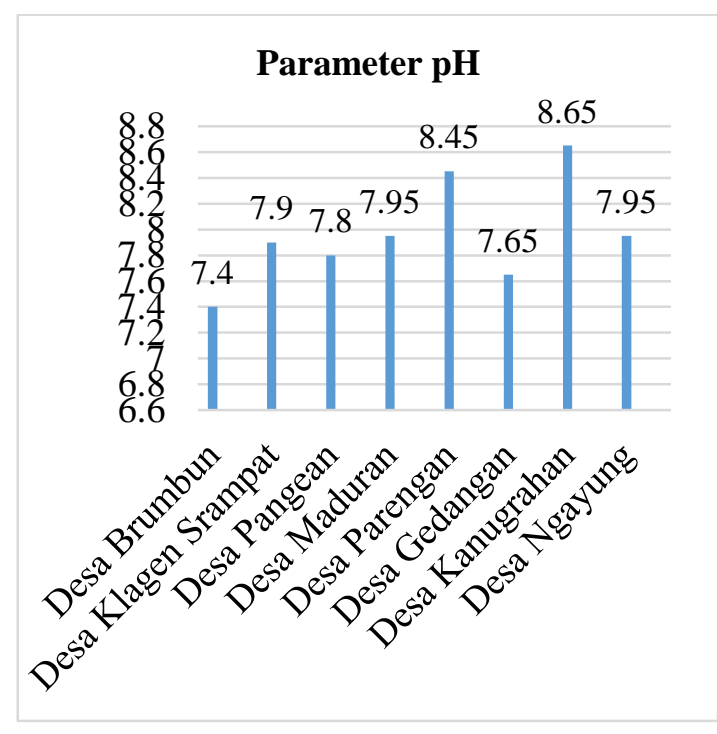

Gambar 5. Nilai pH Air Tanah di Kecamatan Maduran

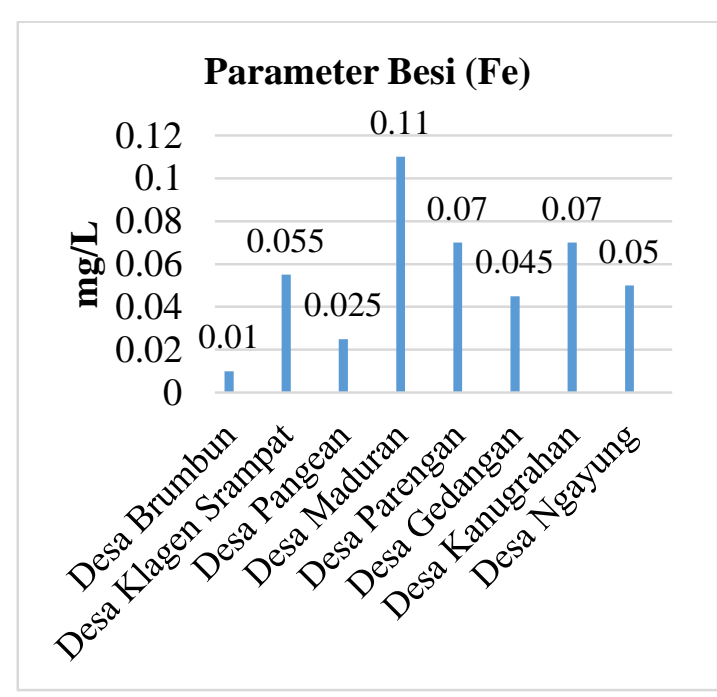

Gambar 6. Nilai Fe Air Tanah di Kecamatan Maduran

\section{Parameter Kesadahan (CaCO3)}

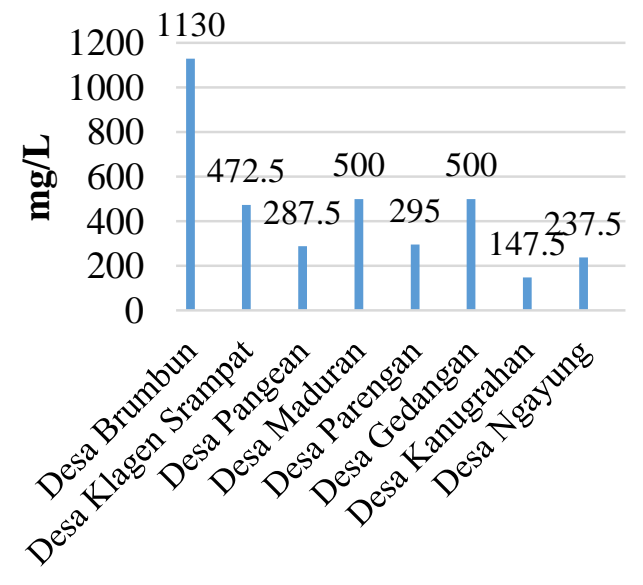

Gambar 7. Nilai Kesadahan Air Tanah di Kecamatan Maduran 
Pengujian parameter Mangan (Mn) pada Gambar 8, air tanah di Kecamatan Maduran termasuk di bawah baku mutu. Baku mutu yang ditetapkan adalah $0.5 \mathrm{mg} \mathrm{L}^{-1}$. Kadar Mangan (Mn) yang kecil dapat disebabkan oleh litologi atau batuan penyusun tanah memiliki unsur kandungan yang rendah (Mursyid \& Mahreda, 2014).

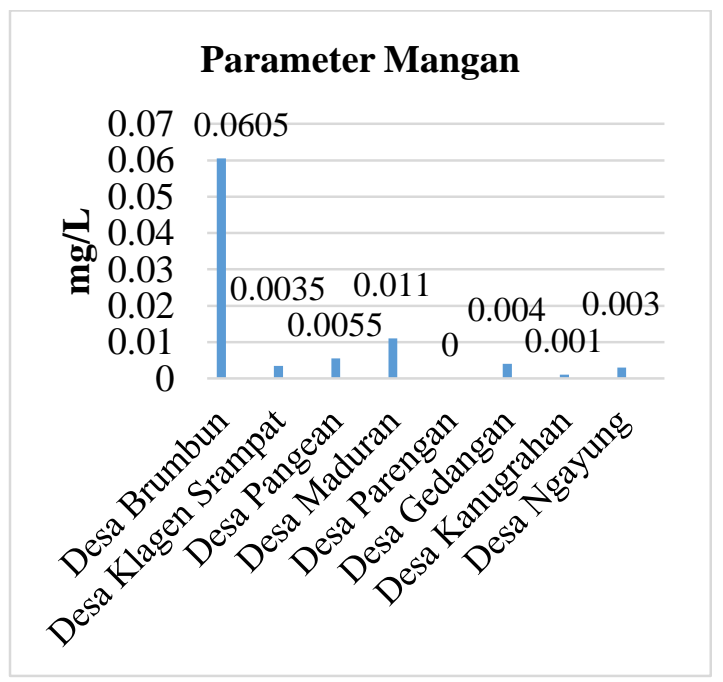

Gambar 8. Nilai Mangan Air Tanah di Kecamatan Maduran

Pengujian kadar Nitrat pada Gambar 9, menunjukkan nilai Nitrat di seluruh stasiun dibawah baku mutu. Baku mutu yang ditetapkan adalah $10 \mathrm{mg} \mathrm{L}^{-1}$. Tinggi rendahnya kadar nitrat di lokasi penelitian dapat dikaitkan dengan musim pengambilan sampel. Sampel penelitian di ambil pada musim kemarau. Selama musim kemarau kadar nitrat kemungkinan berkurang oleh mekanisme biokimia pada air (Twort et al., 2000).

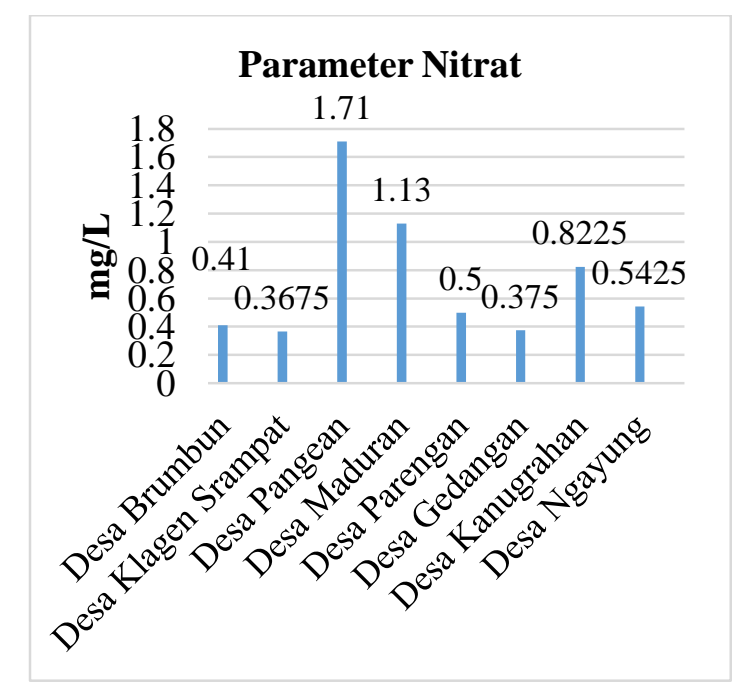

Gambar 9. Nilai Nitrat Air Tanah di Kecamatan Maduran

Hasil pengujian parameter nitrit pada Gambar 10, menunjukkan kadar Nitrit di bawah baku mutu yang telah ditetapkan yaitu $1 \mathrm{mg} \mathrm{L}^{-1}$. Kandungan nitrit di air tanah dapat disebabkan oleh letak sumur gali terhadap sumber air permukaan seperti persawahan dan sungai, jarak antara sumur gali dengan lokasi persawahan dapat berpotensi pencemaran nitrit sebagai dampak dari pemupukan tanaman. Selain itu, peningkatan kadar nitrit juga dapat dipengaruhi oleh sistem saluran pembuanga limbah domestik yang akan menambah konsentrasi kadar nitrit (Prabowo, 2016).

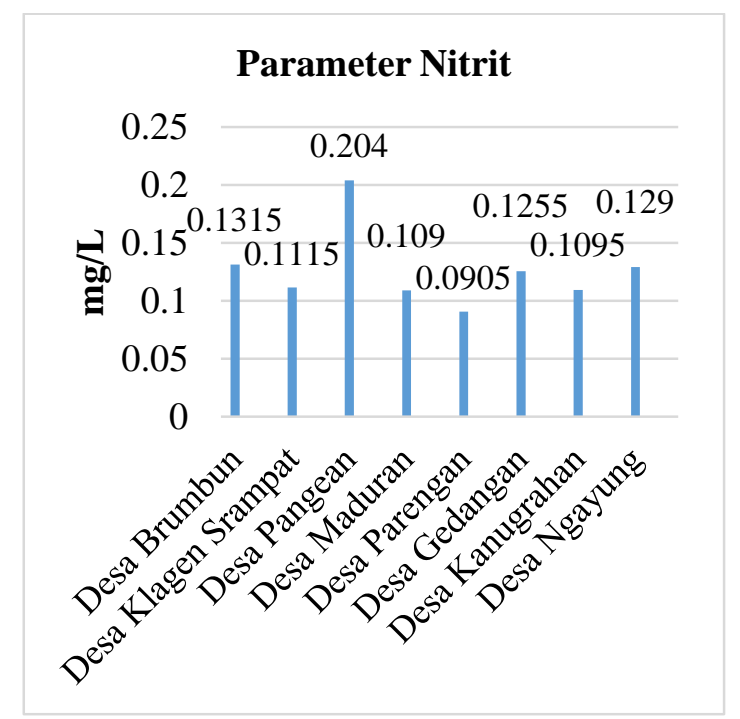

Gambar 10. Nilai Nitrit Air Tanah di Kecamatan Maduran

\section{Analisis Metode Indeks Pencemaran}

Metode Indeks Pencematan (IP) untuk mengetahui status mutu air tanah yang telah dihitung, maka berikut rekapitulasi hasil perhitungan pada tabel 4 .

Tabel 4. Rekapitulasi Hasil Pollution Index

\begin{tabular}{|c|c|c|c|c|}
\hline No. & Stasiun & Lokasi Sumur & $\begin{array}{l}\text { Pollution } \\
\text { Index }\end{array}$ & Keterangan \\
\hline 1. & A & Desa Brumbun & 2,179 & $\begin{array}{l}\text { Cemar } \\
\text { Ringan }\end{array}$ \\
\hline 2. & B & $\begin{array}{c}\text { Desa Klagen } \\
\text { Srampat }\end{array}$ & 0,703 & Kondisi Baik \\
\hline 3. & $\mathrm{C}$ & Desa Pangean & 0,609 & Kondisi Baik \\
\hline 4. & $\mathrm{D}$ & Desa Maduran & 1,134 & $\begin{array}{l}\text { Cemar } \\
\text { Ringan }\end{array}$ \\
\hline 5. & $\mathrm{E}$ & Desa Parengan & 0,700 & Kondisi Baik \\
\hline 6. & $\mathrm{~F}$ & Desa Gedangan & 0,731 & Kondisi Baik \\
\hline 7. & G & Desa Kanugrahan & 0,954 & Kondisi Baik \\
\hline 8. & $\mathrm{H}$ & Desa Ngayung & 1,248 & $\begin{array}{l}\text { Cemar } \\
\text { Ringan }\end{array}$ \\
\hline
\end{tabular}

Hasil rekapitulasi pada Gambar 11, menunjukkan 3 Stasiun memiliki status mutu air tanah yang dikategorikan Cemar Ringan. Sedangkan 5 lokasi lainnya dikategorikan sebagai Memenuhi Baku Mutu/Kondisi Baik. 


\section{Indeks Pencemaran}

- Nilai PIj

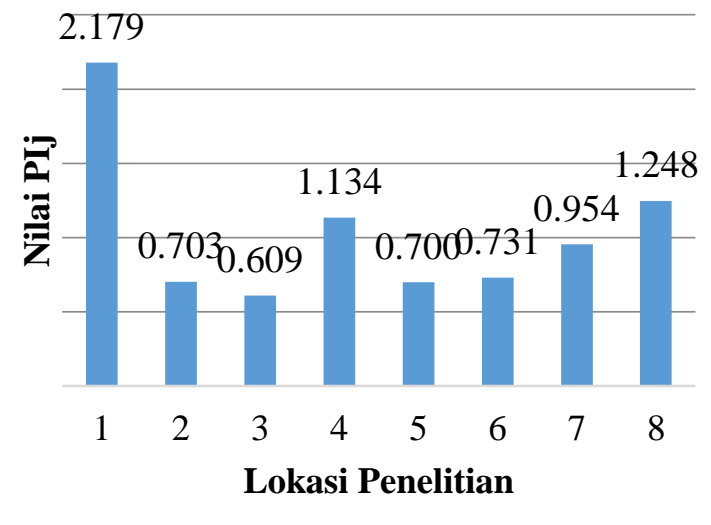

Gambar 11. Rekapitulasi Skor IP

\section{SIMPULAN}

Kualitas air tanah untuk setiap stasiun memiliki nilai yang berbeda-beda. Terdapat 3 lokasi yang melebihi baku mutu. Stasiun tersebut adalah Stasiun A dengan nilain TDS senilai 2,490 $\mathrm{mg} \mathrm{L}^{-1}$ dan Kesadahan 1,130 $\mathrm{mg} \mathrm{L}^{-1}$. Stasiun D dengan nilai 1,284 $\mathrm{mg} \mathrm{L}^{-1}$ dan kesadahan $500 \mathrm{mg}$ $\mathrm{L}^{-1}$. Sedangkan, Stasiun $\mathrm{H}$ meliputi nilai TDS sebesar 1,389 $\mathrm{mg} \mathrm{L}^{-1}$.

Status mutu air tanah yang ditetapkan berdasarkan pada penilaian skor Indeks Pencemaran (IP) terdapat 3 stasiun yaitu Stasiun A, Stasiun D, dan Stasiun H yang dikategorikan sebagai Cemar Ringan. Sedangkan, 5 stasiun lainnya yaitu Stasiun B, Stasiun C, Stasiun E, Stasiun F, dan Stasiun G dikategorikan sebagai Memenuhi Baku Mutu.

\section{DAFTAR PUSTAKA}

Afrianita, R., T. Edwin dan A. Alawiyah. 2017. Analisis Intrusi Air Laut dengan Pengukuran Total Dissolved Solids (TDS) Air Sumur Gali di Kecamatan Padang Utara. Jurnal Dampak, 14(1), 62. $\quad$ https://doi.org/10.25077/dampak.14.1.6272.2017

Astuti, D.W., S. Fatimah dan S. Anie. 2016. Analisis Kadar Kesadahan Total Pada Air Sumur Di Padukuhan Bandung Playen Gunung Kidul Yogyakarta. Analytical and Environmental Chemistry, Volume 1, No. 1, 5.

Azis, A., H. Yusuf, Z. Faisal and M. Suradi. 2015. Water Turbidity Impact on Discharge Decrease of
Groundwater Recharge in Recharge Reservoir. Procedia Engineering, 125, 199-206. https://doi.org/10.1016/j.proeng.2015.11.029

Citaningtyas, S.D. 2019. Uji Kualitas Air Tanah Warga Terhadap Sumber Potensi Cemaran Berdasarkan Keadaan Ekologis Di Kampung Soropadan, Depok, Sleman, Yogyakarta. Universitas Sanata Dharma.

Dohare, D., S. Deshpande and A. Kotiya. 2014. Analysis of Ground Water Quality Parameters: A Review. Research Journal of Engineering Sciences, 3, 6.

Fajarini, S. 2014. Analisis Kualitas Air Tanah Masyarakat di Sekitar Tempat Pembuangan Akhir (TPA) Sampah Kelurahan Sumur Batu Bantar Gebang, Bekasi Tahun 2013. UIN Syarif Hidayatullah.

Hapsari, D. 2015. Kajian Kualitas Air Sumur Gali dan Perilaku Masyarakat di Sekitar Pabrik Semen Kelurahan Karangtalun Kecamatan Cilacap Utara Kabupaten Cilacap. Jurnal Sains \&Teknologi Lingkungan, $\quad 7(1), \quad 18-28$. https://doi.org/10.20885/jstl.vol7.iss1.art2

Lee, J.Y. and J.S. Hahn. 2006. Characterization of groundwater temperature obtained from the Korean national groundwater monitoring stations: Implications for heat pumps. Journal of Hydrology, 329(3-4), 514-526. https://doi.org/10.1016/j.jhydrol.2006.03.007

Mursyid, A. dan E.S. Mahreda. 2014. Analisis Kandungan Besi (Fe), Mangan (Mn), Dan Ph Air Tanah Hasil Pemboran Geoteknik Di Tambang Batubara PT Adaro Indonesia Kabupaten Tabalong Dan Balangan Provinsi Kalimantan Selatan. 9.

Ningrum, S.O. 2018. Analysis Quality of Water River and Quality of Well Water in The Surrounding of Rejo Agung Baru Sugar Factory Madiun. Jurnal Kesehatan Lingkungan, 10(1), 1. https://doi.org/10.20473/jkl.v10i1.2018.1-12

Nurraini, Y. 2011. Kualitas Air Tanah Dangkal Di Sekitar Tempat Pembuangan Akhir (Tpa) Cipayung Kota Depok. 106.

Pawari, M.J. and S. Gawande. 2015. Ground Water Pollution \& Its Consequences. 3(4), 4.

Prabowo, R. 2016. Kadar Nitrit Pada Sumber Air Sumur Di Kelurahan Meteseh, Kec. Tembalang, Kota Semarang. Jurnal Ilmiah Cendekia Eksakta, 7.

Twort, A.C., D.D. Ratnayaka and M.J. Brandt. 2000. Water supply (5th ed). Arnold/IWA Pub. 